\title{
Pemasaran Media Sosial dan Ekuitas Merek Portal Beasiswa pada PT. Integra Solusi Teknotama Bandung
}

\author{
Puspa Wulandari ${ }^{\mathrm{a}}$, Farida Yuliaty ${ }^{\mathrm{b}}$ \\ ${ }^{a, b}$ Universitas Sangga Buana YPKP, Bandung \\ puspawulandari290399@gmail.com
}

\begin{abstract}
Abstrak
Penelitian ini bertujuan untuk mengetahui gambaran mengenai pemasaran media sosial (X), ekuitas merek (Y), dan besar pengaruh pemasaran media sosial terhadap ekuitas merek Portal Beasiswa. Penelitian ini menggunakan metode kuantitatif dengan jenis penelitian asosiatif. Teknik pengambilan sampel menggunakan probability sampling berupa simple random sampling dengan jumlah responden sebanyak tujuh puluh delapan orang. Teknik analisis data menggunakan statistika inferensial, Method of Succesive Interval, uji hipotesis simultan, uji hipotesis parsial, dan uji koefisien determinasi. Berdasarkan hasil analisis inferensial menunjukkan kedua variabel berada pada kategori yang baik. Hasil uji F dan uji t menyatakan bahwa pemasaran media sosial berpengaruh terhadap ekuitas merek Portal Beasiswa. Hasil uji koefisien determinasi menunjukkan bahwa pemasaran media sosial memiliki pengaruh terhadap ekuitas merek Portal Beasiswa sebesar tiga puluh koma dua persen dan sebesar enam puluh sembilan koma delapan persen dipengaruhi oleh faktor lain. Dapat disimpulkan bahwa pemasaran media sosial berpengaruh terhadap ekuitas merek Portal Beasiswa sebesar tiga puluh koma dua persen dan sebesar enam puluh sembilan koma delapan persen dipengaruhi oleh faktor lain, serta kedua variabel ini dianggap sudah berada dalam kategori yang baik dimata audiens.
\end{abstract}

Kata Kunci : Pemasaran Media Sosial, Ekuitas Merek, Instagram.

\section{Abstract}

This study aims to determine the description of social media marketing $(X)$, brand equity $(Y)$, and the magnitude of the influence of social media marketing on the brand equity of the Scholarship Portal. This study uses quantitative methods with associative research types. The sampling technique used probability sampling in the form of simple random sampling with the number of respondents as many as seventy eight people. The data analysis technique used inferential statistics, Method of Succesive Interval, simultaneous hypothesis testing, partial hypothesis testing, and coefficient of determination test. Based on the results of inferential analysis, both variables are in a good category. The results of the F test and t test state that social media marketing has an effect on the brand equity of the Scholarship Portal. The coefficient of determination test results show that social media marketing has an effect on the brand equity of the Scholarship Portal by thirty point two percent and sixty nine point eight percent influenced by other factors. It can be concluded that social media marketing affects the brand equity of the Scholarship Portal by thirty point two percent and by sixty nine point eight percent is influenced by other factors, and these two variables are considered to be in a good category in the eyes of the audience.

Keywords : Social Media Marketing, Brand Equity, Instagram.

\section{PENDAHULUAN}

Dalam dunia bisnis saat ini pemasaran media sosial menjadi salah satu sasaran strategi pemasaran digital yang efektif diantara strategi pemasaran lainnya. Hal ini dikarenakan banyaknya jumlah pengguna media sosial yang setiap tahunnya terus bertambah. Hal ini dibuktikan dari hasil perhitungan presentase penelitian oleh Hootsuite (We are Social) mengenai keadaan total pengguna media sosial di Indonesia yang terbukti adanya peningkatan total pengguna akun media sosial sebanyak 10 juta akun dari Januari 2020 ke Januari 2021.

Pemasaran media sosial adalah teknik strategi pemasaran produk secara digital melalui platform media sosial yang ada. Pemasaran media sosial menjadi pilihan banyak perusahaan sebagai bentuk strategi pemasaran produk milik perusahaan tersebut. Tentunya dengan melalui pemasaran media sosial ini akan berpengaruh terhadap ekuitas merek produk perusahaan terkait. Pemasaran media sosial menjadi alternatif pemasaran yang lebih dipercaya dan lebih bersaing dengan media massa tradisional seperti televisi, radio, dan surat kabar" (Jati, 2021:6).

Ekuitas merek atau yang sering disebut sebagai brand equity adalah nilai kekuatan suatu merek yang perlu terus diperhatikan kualitasnya untuk menciptakan kepuasan target konsumen. Firmansyah (2019:149) menyatakan bahwa ekuitas merek adalah nilai kekuatan dari suatu merek tertentu. Bila dilihat dari perspektif konsumen ekuitas merek ini merupakan suatu bentuk tanggapan dari konsumen terhadap suatu merek.

Portal Beasiswa merupakan salah satu proyek pengembangan perusahaan dibidang perangkat lunak yang mana proyek Portal Beasiswa ini bertujuan untuk mempublikasikan konten informasi beasiswa mulai dari beasiswa tingkat SMA/SMK/sederajat hingga Perguruan Tinggi Negeri/Swasta/Internasional kepada target audiens baik dari dalam maupun luar pengikut akun media sosial Instagram Portal Beasiswa.

41 | JURNAL DIMMENSI | Vol.2 | No.1 | 2022 
Pokok permasalahan pada penelitian terletak pada kurangnya jumlah Sumber Daya Manusia (SDM) dan dana dalam menunjang jalannya pemasaran media sosial pada Instagram proyek pengembangan Portal Beasiswa. Penelitian ini bertujuan untuk menguraikan gambaran pemasaran media sosial (X), ekuitas merek (Y), dan besar pengaruh pemasaran media sosial terhadap ekuitas merek Portal Beasiswa.

Berdasarkan latar belakang masalah penelitian yang telah diuraikan diatas, maka dapat diidentifikasi masalah yang akan dikaji pada penelitian ini adalah sebagai berikut :

a. Bagaimana pemasaran media sosial pada Instagram Portal Beasiswa di PT. Integra Solusi Teknotama (Instama)?

b. Bagaimana ekuitas merek pada Instagram Portal Beasiswa di PT. Integra Solusi Teknotama (Instama)?

c. Berapa besar pengaruh pemasaran media sosial terhadap ekuitas merek Portal Beasiswa di PT. Integra Solusi Teknotama (Instama)?

Tujuan penelitian ini adalah untuk mengetahui :

a. Pemasaran media sosial pada Instagram Portal Beasiswa

b. Ekuitas merek pada Instagram Portal Beasiswa

c. Besar pengaruh pemasaran media sosial terhadap ekuitas merek Portal Beasiswa.

\section{TINJAUAN PUSTAKA}

Menurut Masram dan Mu'ah (2015:42), definisi-definisi umum mengenai manajemen yang sudah ada sebelumnya dapat disimpulkan bahwa manajemen dapat dipahami sebagai ilmu, seni, proses, dan profesi. Menurut Masram dan Mu'ah (2015:77), unsur manajemen terbagi menjadi beberapa unsur yang dikenal dengan sebutan $6 \mathrm{M}+\mathrm{I}$, yaitu :

a. Man atau Sumber Daya Manusia (SDM), merupakan salah satu dari unsur manajemen yang sangat penting untuk mencapai tujuan perusahaan.

b. Money atau dana, merupakan suatu unsur manajemen penting yang dibutuhkan untuk memenuhi kebutuhan produksi perusahaan.

c. Material atau bahan baku, merupakan suatu unsur dari manajemen untuk melengkapi pembuatan produk.

d. Machine atau mesin, merupakan salah satu dari unsur manajemen yang mendukung kegiatan proses produksi yang dijalankan oleh perusahaan.

e. Methode atau metode, merupakan suatu unsur manajemen yang berperan aktif dalam mekanisme kerja agar kegiatan proses produksi dapat berjalan dengan efektif dan efisien.

f. Market atau pasar, merupakan salah satu unsur dari manajemen dalam pemasaran produk yang telah diproduksi agar distribusi produk dapat berjalan dengan lancar sesuai dengan harapan.

g. Information atau informasi, merupakan unsur manajemen yang sangat dibutuhkan oleh perusahaan guna menganalisis produk yang akan maupun yang telah dipasarkan.

\section{Pemasaran}

Sudaryono (2016:42) menyatakan bahwa pemasaran merupakan suatu bentuk aktivitas dalam rangka mengetahui kebutuhan konsumen melalui penciptaan, penawaran, dan pertukaran produk dan jasa yang memiliki nilai serta mengembangkan promosi, distribusi, pelayanan, dan harga dalam upaya memberikan kepuasan tersendiri terhadap kebutuhan konsumen.

\section{Komunikasi Pemasaran Terpadu}

Firmansyah (2020:30) menyatakan bahwa komunikasi pemasaran terpadu merupakan sebuah konsep strategis dalam rangka memperkenalkan nilai tambah suatu produk yang ditawarkan perusahaan guna mencapai tujuan keuntungan yang maksimal.

Menurut Tjiptono (2016:281), bauran komunikasi pemasaran terpadu terdiri dari lima elemen ialah sebagai berikut :

a. Pengiklanan atau advertising merupakan suatu bentuk promosi baik berbentuk barang atau jasa yang dibayar oleh sponsor.

b. Promosi penjualan atau sales promotion merupakan kegiatan pemasaran dalam berbagai macam insentif jangka pendek guna meningkatkan penjualan.

c. Hubungan masyarakat atau public relations merupakan segala bentuk program yang memiliki tujuan untuk menjalin hubungan yang baik dengan berbagai kalangan masyarakat dan menjaga citra perusahaan.

d. Penjualan personal atau personal selling merupakan interaksi tatap muka yang dijalin oleh wiraniaga perusahaan dengan pelanggan untuk melakukan presentasi.

e. Pemasaran langsung atau direct marketing merupakan suatu bentuk hubungan komunikasi yang dilakukan secara langsung dengan target konsumen yang dipilih secara spesifik dalam rangka memperoleh jawaban langsung dari konsumen.

\section{Pemasaran Digital}

Sabila (2019:23) menyatakan bahwa pemasaran digital merupakan suatu bentuk teknik pemasaran secara digital untuk menawarkan produk barang atau jasa dari perusahaan kepada konsumen dalam rangka menjangkau target pasar secara efektif.

Menurut Sabila (2019:27), aktivitas pemasaran digital terbagi menjadi enam media pendukung ialah sebagai berikut :

a. Ponsel, sebagaimana media ponsel ini rata-rata digunakan oleh setiap perusahaan dalam memudahkan aktivitas pemasaran produk barang atau jasanya secara digital melalui aplikasi mobile phone seperti halnya Whatsapp, Line, Kakao Talk, dan sebagainya.

b. Pemasaran media sosial merupakan teknik strategi pemasaran produk secara digital melalui platform media sosial yang ada.

c. Search Engine Marketing (SEM) merupakan salah satu bentuk jenis pemasaran digital yang mana menjadi salah satu cara untuk membuat website perusahaan tersebut 
menjadi lebih mudah dan cepat ditemukan dalam mesin pencari.

d. Search Engine Optimization (SEO) merupakan salah satu bentuk jenis pemasaran digital yang mana menjadi salah satu cara untuk membuat website perusahaan tersebut lebih mudah ditemukan dalam mesin pencari tetapi dalam proses penemuan website terkait dianggap tidak secepat penemuan website seperti melalui media pendukung Search Engine Marketing (SEM).

e. Email marketing, melalui media pendukung ini perusahaan dapat memberikan informasi terkait promosi produk barang atau jasa terbarunya.

f. Pesan teks merupakan salah satu media yang dapat membantu dan sangat mudah dalam penggunaanya terutama dalam memberikan informasi mengenai produk barang atau jasa dari perusahaan atau sejenisnya.

\section{Pemasaran Media Sosial}

"Social Media Marketing is a challenging field for such measurements, due to various conceptual and measurement issues" (Aiello et al, 2016:7).

"The use of social media is growing daily and its use in the recruitment process seems to have grown exponentially" (Koch et al, 2018:1).

Sabila (2019:40) menyatakan bahwa media sosial merupakan wadah atau media secara online yang mana dapat memudahkan pengguna dalam penggunaanya seperti dalam hal berbagi atau bertukar berbagai macam informasi baik yang bersumber dari eksternal maupun internal, sebagai sarana untuk saling berinteraksi satu sama lain, online bisnis dan sebagainya.

Berdasarkan penjelasan diatas dapat dikatakan bahwa media sosial dapat digunakan sebagai wadah atau media pelaku bisnis dalam berbisnis secara online. Media sosial dianggap sebagai media strategi yang efektif dan efisien dalam melakukan pemasaran produk barang atau jasa yang sering dikenal dengan sebutan pemasaran media sosial. Berikut contoh macam-macam media sosial yang sering digunakan oleh pelaku bisnis dalam memasarkan produknya, yaitu :

a. Instagram, merupakan suatu aplikasi media sosial baik yang dapat diakses melalui aplikasi mobile phone maupun website yang memiliki manfaat dalam hal berbagi foto maupun video yang dengan mudah dapat ditemukan oleh pengguna Instagram lainnya.

b. Twitter, merupakan suatu aplikasi media sosial baik yang dapat diakses melalui aplikasi mobile phone maupun website yang memiliki manfaat dalam hal berbagi maupun bertukar pesan dalam berbentuk teks, foto, maupun video.

c. Facebook, merupakan suatu aplikasi media sosial baik yang dapat diakses melalui aplikasi mobile phone maupun website yang memiliki manfaat tidak jauh beda seperti layanan jejaring sosial Twitter.

"Social media marketing activities have been considered as entertainment, interaction, trendiness, and customization" (Bilgin, 2018:131).
Berdasarkan pernyataan (Bilgin, 2018:131), Safitri (2020:16) memberikan penjelasan mengenai masing-masing dari aktivitas kegiatan pemasaran media sosial tersebut, ialah sebagai berikut :

a. Entertainment adalah salah satu dimensi yang penting guna mendorong perilaku yang akan menyebabkan emosi positif pengikut dari media sosial pada merek terkait. Alasan setiap individual dalam menggunakan media sosial akan berbeda dan setiap audiens memiliki suatu bentuk empati pada setiap konten yang menarik perhatiannya.

b. Interaction merupakan komunikasi dasar yang mana terjadi adanya pertukaran informasi dan dimana pengguna akan berinteraksi satu sama lain, berkontribusi dalam diskusi, serta memberikan saran terhadap produk jasa tertentu. Interaksi memiliki salah satu fungsi sebagai motivator dalam rangka membantu pembuatan konten berdasarkan sudut pandang pengguna. Selain itu, antara merek dengan konsumen memiliki hubungan guna meningkatkan afinitas dan kredibilitas.

c. Trendiness merupakan salah satu dimensi pada pemasaran media sosial yang mana didalamnya terdapat perkenalan informasi produk terbaru kepada konsumen. Konsumen akan mempertimbangkan informasi yang diberikan oleh media sosial itu sendiri yang mana informasi yang dapat lebih dipercaya dibandingkan informasi yang diberikan dari media tradisional. Konsumen akan menginginkan segala hal yang terkini tentang lingkungannya.

d. Customization adalah sebuah dimensi aktivitas yang mana sudut pandang konsumen lebih penting untuk mempersiapkan layanan dan dorongan utama kustomisasi yaitu kepuasan pelanggan. Media sosial suatu merek dapat dikustomisasi berdasarkan kebutuhan konsumen dan baiknya disampaikan secara personal. Hal ini akan dapat membantu guna membangun kesetiaan konsumen terhadap merek itu sendiri. Terdapat dua jenis level kustomisasi yang diunggah pada media sosial yaitu siaran dan customized message. Target konsumen untuk pesan siaran ialah semua orang dalam media sosial yang memiliki ketertarikan dan target konsumen customized message yaitu biasanya kelompok kecil atau orang tertentu.

\section{Ekuitas Merek}

Firmansyah (2019:149) menyatakan bahwa ekuitas merek atau brand equity adalah kekuatan dari sebuah merek, sedangkan berdasarkan perspektif konsumen ekuitas merek merupakan suatu bentuk tanggapan dari konsumen terhadap suatu merek. nilai tambah yang diberikan pada produk dan jasa.

Menurut David Allen Aaker (2018:15), ekuitas merek dikelompokkan kedalam empat dimensi yang dapat dijadikan indikator dalam menilai ekuitas merek, yaitu sebagai berikut

a. Brand awareness (kesadaran merek) menunjukkan kesanggupan seorang calon pembeli untuk mengenali, 
mengingat kembali suatu merek sebagai bagian dari suatu kategori produk tertentu.

b. Perceived quality (persepsi kualitas) dapat didefinisikan sebagai persepsi pelanggan terhadap keseluruhan kualitas atau keunggulan suatu produk berkaitan dengan apa yang diharapkan oleh konsumen.

c. Brand association (asosiasi merek) merupakan segala kesan yang muncul dibenak seorang yang terkait dengan ingatannya mengenai suatu merek.

d. Brand loyalty (loyalitas merek) merupakan suatu ukuran keterkaitan konsumen kepada sebuah merek.

\section{METODE PENELITIAN}

Penelitian ini menggunakan metode kuantitatif dengan jenis penelitian asosiatif. Hardani et al (2020:39) menyatakan bahwa penelitian kuantitatif adalah metode dengan data penelitian berupa angka-angka, mulai dari pengumpulan data, penafsiran data, hingga penyajian hasil. Jenis penelitian yang asosiatif merupakan jenis penelitian yang bersifat kausal yang mana terdapat dua atau lebih variabel dan dianggap memiliki hubungan sebab akibat. Penelitian ini menggunakan dua jenis variabel, yaitu pemasaran media sosial (X) dan ekuitas merek (Y).
Teknik pengumpulan data yang digunakan dalam penelitian ini terdiri dari pengumpulan data primer dengan teknik survei melalui angket dan pengumpulan data sekunder melalui studi kepustakaan. Populasi dalam penelitian ini adalah anggota dari grup Whatsapp Portal Beasiswa yang mana keanggotaannya terdiri dari 336 anggota. Anggota grup Whatsapp Portal Beasiswa akan diberikan bentuk angket dan disebar dalam bentuk link melalui Whatsapp person contact serta diisi secara online melalui google form.

Teknik pengambilan sampel yang digunakan pada penelitian ini adalah probability sampling. "Probability sampling adalah teknik pengambilan sampel yang memberikan peluang atau kesempatan yang sama bagi setiap unsur atau anggota populasi untuk dipilih menjadi sampel" (Sugiyono, 2017:82). Teknik ini menggunakan simple random sampling. Sugiyono (2017:82), menyatakan bahwa simple random sampling adalah pengambilan anggota sampel dari populasi yang dilakukan secara acak tanpa memperhatikan strata yang ada dalam populasi tersebut. Metode pengambilan sampel diterangkan dengan menggunakan rumus Slovin dalam rangka mengetahui jumlah sampel yang akan diteliti, yaitu :

$$
\begin{aligned}
& \mathrm{n}=\frac{N}{1+N \mathrm{e}^{2}} \\
& \mathrm{n}=\frac{336}{1+(336)(0,1)^{2}} \\
& \mathrm{n}=77,06=78
\end{aligned}
$$

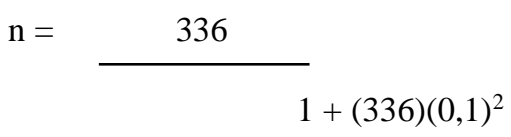

Keterangan :

$\mathrm{n}=$ Jumlah anggota sampel

$N=$ Jumlah anggota populasi

$e=$ Error level (tingkat kesalahan) umumnya digunakan $1 \%$ atau 0,01 , $5 \%$ atau 0,05 , dan $10 \%$ atau 0,1 .

Berdasarkan perhitungan rumus Slovin diatas diperoleh jumlah sampel minimal sebanyak 78 responden. Teknik analisis data pada penelitian ini menggunakan statistika inferensial, Method of Succesive Interval, uji hipotesis

\section{HASIL DAN PEMBAHASAN}

\section{Hasil Analisis Inferensial Variabel Pemasaran Media Sosial (X)}

Berdasarkan pengumpulan data dari teknik angket yang telah dilakukan kepada 78 responden atau anggota Whatsapp simultan, uji hipotesis parsial, dan uji koefisien determinasi dengan bantuan pengolah data statistik menggunakan IBM SPSS version 28.0.0.0 (190).

Group Portal Beasiswa yang mana terdapat tujuh item pernyataan yang mewakili variabel pemasaran media sosial (X) yang diajukan kepada responden dengan pilihan alternatif jawaban skala lima. Berikut dibawah ini presentasi skor pada seluruh indikator variabel $\mathrm{X}$, yaitu : 
Tabel 4.1

Presentasi Skor Variabel X

\begin{tabular}{|c|c|c|c|c|}
\hline No. & Indikator & $\sum$ Skor & $\begin{array}{l}\text { \% } \\
\text { Skor }\end{array}$ & $\begin{array}{l}\text { Skor } \\
\text { Ideal }\end{array}$ \\
\hline 1. & Tampilan konten pada Instagram Portal Beasiswa terlihat baik dan menarik. & 311 & $80 \%$ & 390 \\
\hline 2. & $\begin{array}{l}\text { Pada Instagram Portal Beasiswa sangat memungkinkan untuk berbagi informasi } \\
\text { dengan orang lain. }\end{array}$ & 337 & $86 \%$ & 390 \\
\hline 3. & $\begin{array}{l}\text { Pada Instagram Portal Beasiswa dapat dilakukan percakapan maupun pertukaran } \\
\text { opini. }\end{array}$ & 325 & $83 \%$ & 390 \\
\hline 4. & $\begin{array}{l}\text { Pada Instagram Portal Beasiswa selalu bersedia menjawab komentar dan pertanyaan } \\
\text { dari konsumen. }\end{array}$ & 313 & $80 \%$ & 390 \\
\hline 5. & Instagram Portal Beasiswa selalu memberikan informasi terkini pada konsumen & 325 & $83 \%$ & 390 \\
\hline 6. & Instagram Portal Beasiswa selalu memberikan layanan yang informatif. & 336 & $86 \%$ & 390 \\
\hline 7. & $\begin{array}{l}\text { Instagram Portal Beasiswa selalu membagikan informasi beasiswa yang saya } \\
\text { butuhkan }\end{array}$ & 328 & $84 \%$ & 390 \\
\hline Total & & 2.275 & $83 \%$ & 2.730 \\
\hline
\end{tabular}

Berdasarkan keterangan dari Tabel 4.1, menerangkan bahwa total skor dari hasil pengumpulan data angket untuk variabel pemasaran media sosial (X) ialah sebesar 2.275 atau setara dengan $83 \%$ dari total skor ideal. Total persentase skor dari variabel $\mathrm{X}$ ini dapat diinterpretasikan kedalam tafsiran kriteria garis kontinum, yaitu sebagai berikut:

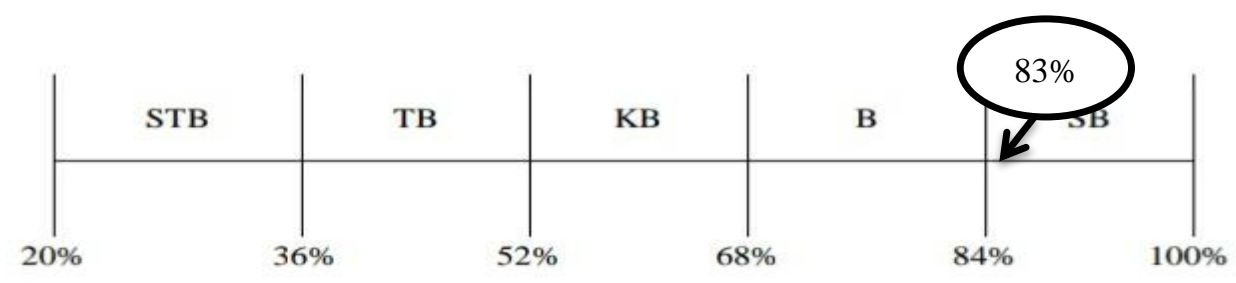

Gambar 4.1

Garis Kontinum Variabel Pemasaran Media Sosial (X)

Berdasarkan Gambar 4.1 diatas menunjukkan bahwa variabel pemasaran media sosial (X) berada pada garis interval $68 \%$ $84 \%$ yaitu sebesar $83 \%$ dan hal ini menyatakan bahwa

\section{Hasil Analisis Inferensial Variabel Ekuitas Merek (Y)}

Berdasarkan pengumpulan data dari teknik angket yang telah dilakukan kepada 78 responden atau anggota Whatsapp Group Portal Beasiswa yang mana terdapat lima item pernyataan yang mewakili variabel ekuitas merek (Y) variabel pemasaran media sosial $(\mathrm{X})$ dalam penelitian ini berada pada kategori atau kriteria yang baik. yang diajukan kepada responden dengan pilihan alternatif jawaban skala lima. Berikut dibawah ini presentasi skor pada seluruh indikator variabel $\mathrm{Y}$, yaitu:

Tabel 4.2

Presentasi Skor Variabel Y

\begin{tabular}{|c|c|c|c|c|}
\hline No. & Indikator & $\sum$ Skor & \% Skor & $\begin{array}{l}\text { Skor } \\
\text { Ideal }\end{array}$ \\
\hline 8. & $\begin{array}{l}\text { Saya akan tetap memilih Portal Beasiswa sebagai pusat informasi beasiswa yang } \\
\text { saya cari. }\end{array}$ & 300 & $77 \%$ & 390 \\
\hline 9. & Saya mengenali merek Portal Beasiswa. & 275 & $71 \%$ & 390 \\
\hline 10. & Saya dapat mengingat logo atau simbol merek Portal Beasiswa dengan cepat. & 293 & $75 \%$ & 390 \\
\hline 11. & $\begin{array}{l}\text { Produk jasa informasi beasiswa dari Portal Beasiswa memiliki inovasi tampilan } \\
\text { desain yang baik.. }\end{array}$ & 295 & $76 \%$ & 390 \\
\hline 12. & $\begin{array}{l}\text { Bagi saya Portal Beasiswa merupakan produk jasa informasi beasiswa yang saya } \\
\text { harapkan }\end{array}$ & 306 & $78 \%$ & 390 \\
\hline \multicolumn{2}{|r|}{ Total } & 1.469 & $75 \%$ & 1.950 \\
\hline
\end{tabular}

Berdasarkan keterangan dari Tabel 4.2, menerangkan bahwa total skor dari hasil pengumpulan data angket untuk variabel ekuitas merek (Y) ialah sebesar 1.469 atau setara dengan $75 \%$ dari total skor ideal. Total persentase skor dari variabel Y ini dapat diinterpretasikan kedalam tafsiran kriteria garis kontinum, yaitu sebagai berikut : 


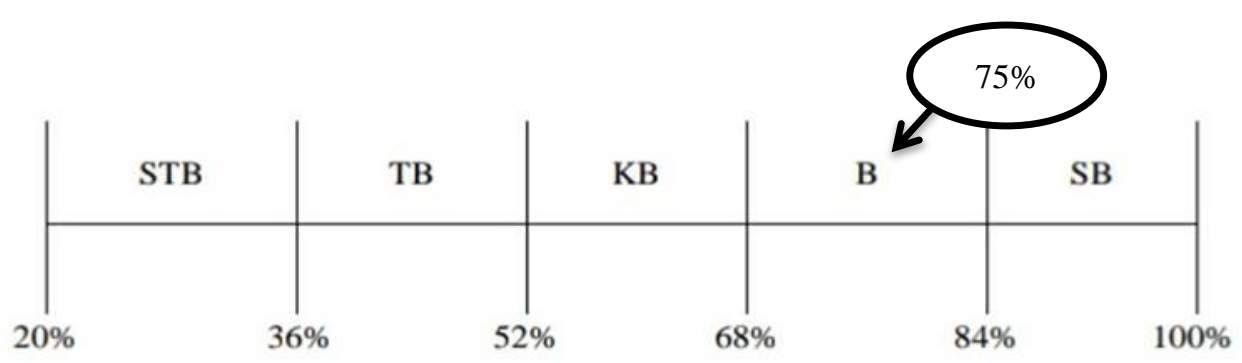

Gambar 4.2

Garis Kontinum Variabel Ekuitas Merek (Y)

Berdasarkan Gambar 4.2 diatas menunjukkan bahwa variabel ekuitas merek (Y) berada pada garis interval $68 \%$ - $84 \%$ yaitu sebesar $75 \%$ dan hal ini menyatakan bahwa variabel ekuitas merek (Y) dalam penelitian ini berada pada kategori atau kriteria yang baik.

\section{Hasil Uji Hipotesis Simultan (Uji F)}

Tabel 4.3

Uji Hipotesis Simultan (Uji F)

ANOVA $^{a}$

\begin{tabular}{clccccc} 
& Model & Sum of Squares & Df & Mean Square & F & Sig. \\
\hline \multirow{2}{*}{1} & Regression & 455.214 & 1 & 455.214 & 32.876 \\
& Residual & 1052.325 & 76 & 13.846 & \\
\cline { 2 - 7 } & Total & 1507.538 & 77 & \\
\cline { 2 - 6 } & \multicolumn{6}{c}{ Sumber : data primer yang sudah diolah, 2021 }
\end{tabular}

1) Dependent Variable : Ekuitas Merek

2) Predictors : (Constant), Pemasaran Media Sosial

Berdasarkan Tabel 4.3 diatas menunjukkan bahwa nilai $\mathrm{F}$ hitung adalah sebesar 32.876 dengan $\mathrm{F}$ sig. <.001 yang mana nilainya lebih kecil dari tingkat signifikansi $(\alpha)=0,05$, maka H0 ditolak. Hal ini dapat diartikan bahwa pemasaran media sosial sebagai variabel independen atau bebas $(\mathrm{X})$ memiliki pengaruh terhadap ekuitas merek sebagai variabel dependen atau terikat (Y).

\section{Hasil Uji Hipotesis Parsial (Uji t)}

Tabel 4.4

Uji Hipotesis Parsial (Uji t)

Coefficients $^{a}$

\begin{tabular}{ccccccc}
\hline & & \multicolumn{2}{c}{ Unstandardized Coefficients } & \multicolumn{2}{c}{ Standardized Coefficients } \\
& Model & B & Std. Error & Beta & T & Sig. \\
\hline \multirow{2}{*}{1} & (Constant) & 6.552 & 1.298 & & 2980 & .004 \\
& Pemasaran Media Sosial & .430 & .075 & .550 & 5.734 & $<.001$ \\
\hline
\end{tabular}

Sumber : data primer yang sudah diolah, 2021

1) Dependent Variable : Ekuitas Merek

Berdasarkan Tabel 4 diatas menunjukkan bahwa nilai t hitung adalah sebesar 5.734 yang lebih kecil dari t tabel yaitu 1.665 dan $\mathrm{t}$ sig. <.001 yang mana $\mathrm{t}$ sig $=0,001$ ini lebih kecil dari tingkat signifikansi $(\alpha)=0,05$, maka $\mathrm{H} 0$ ditolak. Hal ini dapat diartikan bahwa pemasaran media sosial sebagai variabel independen atau bebas (X) memiliki pengaruh terhadap ekuitas merek sebagai variabel dependen atau terikat (Y). 
Hasil Uji Koefisien Determinasi $\left(\mathbf{R}^{2}\right)$

Tabel 4.5

Uji Koefisien Determinasi $\left(\mathrm{R}^{2}\right)$

\section{Model Summary}

\begin{tabular}{clccc} 
Model & $\mathbf{R}$ & $\mathbf{R}$ Square & Adjusted $\mathbf{R}$ Square & $\begin{array}{c}\text { Std. Error of } \\
\text { the Estimate }\end{array}$ \\
\hline 1 & $.550^{\mathrm{a}}$ & .302 & .293 & 3.721 \\
\hline \multicolumn{4}{c}{ Sumber : data primer yang sudah diolah, 2021 }
\end{tabular}

1) Predictors : (Constant), Pemasaran Media Sosial

Berdasarkan Tabel 4.5 diatas menunjukkan bahwa nilai $\mathrm{R}$ Square adalah 0,302 atau jika dipersentasikan ialah 30,2\%. Hal ini dapat diartikan bahwa pemasaran media sosial sebagai variabel independen atau bebas (X) memiliki pengaruh terhadap ekuitas merek sebagai variabel dependen atau terikat (Y) sebesar 30,2\% dan sebesar 69,8\% ekuitas merek Portal Beasiswa dipengaruhi oleh faktor lain.

Pada hasil penelitian ini peneliti mengemukakan bahwa adanya perbedaan antara penelitian yang dilakukan peneliti dengan penelitian terdahulu yaitu terletak pada jumlah persentase pengaruh pemasaran media sosial terhadap ekuitas merek, tetapi secara garis besar persamaannya menyatakan bahwa pemasaran media sosial memiliki pengaruh terhadap ekuitas merek.

\section{Pemasaran Media Sosial pada Instagram Portal Beasiswa}

Berdasarkan hasil analisis deksriptif menyatakan bahwa variabel pemasaran media sosial $(\mathrm{X})$ berada pada garis interval $68 \%$ - $84 \%$ yaitu sebesar $83 \%$ dengan total skor sebesar 2.275 yang menunjukkan bahwa variabel pemasaran media sosial (X) dalam penelitian ini berada pada kategori atau kriteria yang baik dimata konsumen atau audiens. Dalam penelitian ini peneliti dapat mengambil kesimpulan bahwa konsumen atau audiens mempercayai pemasaran media sosial yang dijalankan pada Portal Beasiswa di PT. Integra Solusi Teknotama (Instama) Bandung dapat dikatakan baik berdasarkan dimensi pemasaran media sosial, seperti halnya Entertainment, Interaction, Trendiness, dan Customization.

\section{Ekuitas Merek pada Instagram Portal Beasiswa}

Berdasarkan hasil analisis deksriptif menyatakan bahwa variabel ekuitas merek (Y) berada pada garis interval 68\% $84 \%$ yaitu sebesar $75 \%$ dengan total skor sebesar 1.469 yang menunjukkan bahwa variabel ekuitas merek (Y) dalam penelitian ini berada pada kategori atau kriteria yang baik dimata konsumen atau audiens. Dalam penelitian ini peneliti dapat mengambil kesimpulan bahwa konsumen atau audiens mempercayai ekuitas merek pada Portal Beasiswa di PT. Integra Solusi Teknotama (Instama) Bandung dapat dikatakan sudah berjalan dengan baik berdasarkan dimensi ekuitas merek, seperti halnya loyalitas merek, kesadaran merek, asosiasi merek, dan persepsi kualitas.

\section{Pengaruh Pemasaran Media Sosial terhadap Ekuitas Merek Portal Beasiswa}

Berdasarkan perolehan dari uji hipotesis simultan (uji F) diperoleh nilai $\mathrm{F}$ hitung adalah sebesar 32.876 dengan $\mathrm{F}$ sig. $<.001$ yang mana nilainya lebih kecil dari tingkat signifikansi $(\alpha)=0,05$, maka H0 ditolak. Hal ini dapat diartikan bahwa pemasaran media sosial sebagai variabel independen atau bebas $(\mathrm{X})$ memiliki pengaruh terhadap ekuitas merek sebagai variabel dependen atau terikat $(\mathrm{Y})$.

Sedangkan berdasarkan uji hipotesis parsial (uji t) yang telah dilakukan, diperoleh nilai t hitung adalah sebesar 5.734 yang mana nilainya lebih kecil dari t tabel yaitu 1.665 dan $\mathrm{t}$ sig. $<.001$ yang nilainya lebih kecil dari tingkat signifikansi $(\alpha)=$ 0,05 , maka H0 ditolak. Hal ini dapat diartikan bahwa pemasaran media sosial sebagai variabel independen atau bebas (X) memiliki pengaruh terhadap ekuitas merek sebagai variabel dependen atau terikat (Y).

Selain itu, berdasarkan interpretasi interval koefisien determinasi dalam uji koefisien determinasi $\left(\mathrm{R}^{2}\right)$ yang telah dilakukan menunjukkan bahwa tingkat hubungan antara pemasaran media sosial dengan ekuitas merek Portal Beasiswa di PT. Integra Solusi Teknotama (Instama) Bandung berada pada nilai koefisien 0,550 yang dinyatakan berada pada tingkat hubungan yang cukup tinggi. Hal ini membuktikan bahwa pemasaran media sosial memiliki pengaruh terhadap ekuitas merek Portal Beasiswa dan persentase pengaruh pemasaran media sosial terhadap ekuitas merek Portal Beasiswa ialah sebesar 30,2\% dan sebesar $69,8 \%$ ekuitas merek Portal Beasiswa dipengaruhi oleh faktor lain.

\section{KESIMPULAN}

\section{Hasil Analisis Inferensial Variabel Pemasaran Media Sosial (X)}

Secara penganalisaan inferensial, variabel pemasaran media sosial (X) memiliki rata-rata skor sebesar $83 \%$ dari 7 item pernyataan yang ada. Skor tertinggi pada variabel $\mathrm{X}$ berada pada pernyataan ke-2 dalam indikator interaction yaitu sebesar $86 \%$ yang menyatakan bahwa pada Instagram Portal Beasiswa sangat memungkinkan untuk berbagi informasi dengan orang lain. Selain itu, skor tertinggi pada variabel X lainnya ditunjukkan pada pernyataan ke-6 dalam indikator 
customization yaitu sebesar $86 \%$ yang menyatakan bahwa Instagram Portal Beasiswa selalu memberikan layanan yang informatif.

Skor terkecil pada variabel $\mathrm{X}$ ditunjukkan pada pernyataan ke-1 dalam indikator entertainment yaitu sebesar $80 \%$ yang menyatakan bahwa tampilan konten pada Instagram Portal Beasiswa terlihat baik dan menarik. Selain itu, skor terkecil lainnya ditunjukkan pada pernyataan ke-4 dalam indikator interaction yaitu sebesar $80 \%$ yang menyatakan bahwa pada Instagram Portal Beasiswa selalu bersedia menjawab komentar dan pertanyaan dari konsumen. Jika diinterpretasikan pada garis kontinum, rata-rata skor dari variabel $\mathrm{X}$ berada pada posisi kategori yang baik.

\section{Hasil Analisis Inferensial Variabel Ekuitas Merek (Y)}

Secara penganalisaan inferensial, variabel ekuitas merek (Y) memiliki rata-rata skor sebesar $75 \%$ dari 5 item pernyataan yang ada. Skor tertinggi pada variabel $\mathrm{Y}$ berada pada pernyataan ke-12 dalam indikator persepsi kualitas yaitu sebesar $78 \%$ yang menyatakan bahwa Portal Beasiswa merupakan produk jasa informasi beasiswa yang diharapkan. Sedangkan skor terkecil pada variabel $\mathrm{Y}$ ditunjukkan pada pernyataan ke-9 dalam indikator kesadaran merek yaitu sebesar $71 \%$ yang menyatakan bahwa audiens mengenali merek Portal Beaiswa. Jika diinterpretasikan pada garis kontinum, rata-rata skor dari variabel $\mathrm{Y}$ berada pada posisi kategori yang baik.

\section{Hasil Uji Hipotesis}

Secara hasil pengujian hipotesis, uji hipotesis simultan (uji F) diperoleh nilai $\mathrm{F}$ hitung yaitu sebesar 32.876 dengan $\mathrm{F}$ sig.

\section{DAFTAR PUSTAKA}

\section{Buku:}

Aaker, D. A. (2018). Manajemen ekuitas merek:memanfaatkan nilai dari suatu merek. Alih bahasa: Aris Ananda. Jakarta: Mitra Utama.

Firmansyah, M. A. (2019). Pemasaran produk merek: planning and strategy (edisi 1). Pasuruan, Jawa Timur: Qiara Media. (2020).

Hardani., Auliya, N. H., Andriani, H., Fardani, R. A. Ustiawaty, J., Utami, E. F..., Sukmana D. J., \& Istiqomah, R. R. (2020). Metode penelitian kualitatif dan kuantitatif (edisi 1). Yogyakarta: Pustaka Ilmu.

Masram \& Mu'ah. (2015). Manajemen sumber manusia (edisi 1). Surabaya: Zifatama Publisher.

Sabila, N. (2019). Pengantar belajar digital marketing (edisi 1). Semarang: STEKOM.

Sudaryono. (2016). Manajemen pemasaran: teori dan implementasi (edisi 1). Yogyakarta: Andi.

Sugiyono. (2017). Metode penelitian

kuantitatif, kualitatif, $r \& d$. Bandung: Alfabeta.

Tjiptono, F. (2017). Pemasaran: esensi dan aplikasi (edisi 1). Yogyakarta: Andi.
$<.001$ yang mana nilainya lebih kecil dari tingkat signifikansi $(\alpha)=0,05$, maka H0 ditolak. Hal ini dapat diartikan bahwa pemasaran media sosial sebagai variabel independen atau bebas (X) memiliki pengaruh terhadap ekuitas merek sebagai variabel dependen atau terikat $(\mathrm{Y})$.

Berdasarkan uji hipotesis parsial (uji t) yang telah dilakukan, diperoleh nilai t hitung adalah sebesar 5.734 yang mana nilainya lebih kecil dari t tabel yaitu 1.665 dan $\mathrm{t}$ sig. <.001 yang mana nilainya lebih kecil dari tingkat signifikansi $(\alpha)=$ 0,05 , maka H0 ditolak. Hal ini dapat diartikan bahwa pemasaran media sosial sebagai variabel independen atau bebas $(\mathrm{X})$ memiliki pengaruh terhadap ekuitas merek sebagai variabel dependen atau terikat $(\mathrm{Y})$.

Selain itu, berdasarkan interpretasi interval koefisien determinasi dalam uji koefisien determinasi $\left(\mathrm{R}^{2}\right)$ yang telah dilakukan menunjukkan bahwa tingkat hubungan antara pemasaran media sosial dengan ekuitas merek Portal Beasiswa di PT. Integra Solusi Teknotama (Instama) Bandung berada pada nilai koefisien 0,550 yang dinyatakan berada pada tingkat hubungan yang cukup tinggi. Hal ini membuktikan bahwa pemasaran media sosial memiliki pengaruh terhadap ekuitas merek Portal Beasiswa dan persentase pengaruh pemasaran media sosial terhadap ekuitas merek Portal Beasiswa ialah sebesar 30,2\% dan sebesar $69,8 \%$ ekuitas merek Portal Beasiswa dipengaruhi oleh faktor lain.

\section{Jurnal:}

Aiello, G., Donvito, R.,Godey, B., et al., Manthiou, A., Pederzoli, D., Rokka, J..., Singh Rahul. Social media marketing efforts of luxury brands: influence on brand equity and consumer behavior, 2016.

Bilgin, Y. The effect of social media marketing activities on brand awareness, brand image and brand loyalty", vol. 6, pp. 128-148, 2018.

Koch, T., Gerber, C., \& De Klerk, J. The impact of social media on recruitment: are you linkedIn?,vol.16, 2018 .

Skripsi:

Safitri, A. N. (2014). Pengaruh social media marketing terhadap brand equity dan customer response pada rown division. [Skripsi]. Institut Negara Islam NegeriSurakarta. Surakarta.

Wahyu, A. D. (2019). Pengaruh e-service quality terhadap e-loyalty (survey pada nasabah mobile banking mandiri di Indonesia). [Skripsi]. Universitas Pendidik Indonesia. Bandung. 